\title{
A Morphological and Biometric Study of the Infraorbital Foramen (E2 - Sibai Point) in Adult Skulls
}

\author{
Estudio Morfológico y Biométrico del Foramen Infraorbital \\ (Punto E2 - Sibai) en Cráneos de Adultos
}

${ }^{*}$ Oliveira Junior, E. M. de; ${ }^{* *}$ Moreira, R. T.; ${ }^{* * *}$ Neto, B. L.; ${ }^{* * * * *}$ Silva, C. M. F. da $\&{ }^{* * * * *}$ Lima, F. J. C.

OLIVEIRA JUNIOR, E. M. de; MOREIRA, R. T.; NETO, B. L.; SILVA, C. M. F. da \& LIMA, F. J. C. A. Morphological and biometric study of the infraorbital foramen (E2-Sibai point) in adult skulls. Int. J. Morphol., 30(3):986-992, 2012.

SUMMARY: The objective of this work was to study the morphology and biometry of the infraorbital foramen (FIO), variations in its shape, size and number as well as to obtain measurements of its location. 60 dry skulls were analyzed. The test of Qui-quadrant and the $\mathrm{T}$ Test were used in measurements with a 5\% significance. On the right side, the FIO was measured at a distance of $6.49( \pm 1.68) \mathrm{mm}$ from the lower, 39.65( \pm 3$) \mathrm{mm}$ from the upper, $17.7( \pm 2.97) \mathrm{mm}$ from the medial and 20.46( \pm 2.9$) \mathrm{mm}$ from the lateral margin of the orbit; its pear-shaped opening distance was $13.67( \pm 2.17) \mathrm{mm}$. On the left side, the distance of the FIO to the lower margin of the orbit was $6.52( \pm 1.82) \mathrm{mm}$; to the upper margin was $39.9( \pm 2.62) \mathrm{mm}$ and to the lateral and medial margin were $17.93( \pm 2.58) \mathrm{mm}$ and $21.12( \pm 3)$ $\mathrm{mm}$, respectively; its distance to the pear-shaped opening was $14.26( \pm 1.83) \mathrm{mm}$. It was found predominately in an oval shape, in 39 $(65 \%)$ of the skulls, on both sides. Accessory foramens were present in 11 samples on the right and in 15 samples on the left side. The FIO was most frequently found on the side of, or laterally to the sagittal plane that passes through the middle of the supraorbital foramen/ incisures, in 38 skulls $(63.3 \%)$ on the right side and in 45 skulls $(75 \%)$ on the left and middle to the zigomatic-maxillary suture, in 41 skulls $(68.3 \%)$ on right and in 42 skulls $(70 \%)$ on the left side, besides being most frequently found in a region between the first and second premolars, in 22 skulls $(36.7 \%)$ on the right side and in 17 skulls $(28.3 \%)$ on the left.

KEY WORDS: Infraorbital foramen (E2-Sibai Point); Acupuncture; Biometry.

\section{INTRODUCTION}

The Infraorbital foramen (FIO) is located under the infraorbital margin, varying from 4 to $12 \mathrm{~mm}$ (Testut \& Latarjet, 1954), bilaterally in the maxillary bone (Gardner et al., 1988) and relates to the anterior opening of the infraorbital canal. The point of the orbit right above the infraorbital foramen is noted for its discrete wrinkles, where the zigomatic-maxillary suture crosses the infraorbital margin (Sicher \& Dubrul, 1991). This gives a passageway for the nerves and the infraorbital blood vessels, frequently anesthetized in this foramen (Texeira et al., 2001) and found in a lower medial direction. It appears in a relatively large diameter compared to the supraorbital foramen, with varieties in shape, situation and disposition (Testut \& Latarjet; Berge \& Bergman, 2001).
The point E2 (Sibai - "Always Glowing") is located three decimals from sun or three distal fens from E1 (Chengqui), in an infraorbital bone groove. It is used in the treatment of paralysis and facial spasm, trigeminal neurology, eye disease and maxillary sinusitis.

The technical procedure that is most commonly used in dentistry is anesthesia and, according to Ranali et al. (1988) is the most common method of pain relief used in dentist offices.

A precise understanding of the localization of the foramen and the reference points in the area is of extreme importance in the practice of local anesthesia due to the fact

* Oral and Maxillo-Facial Surgeon Resident of University of São Paulo, USP, and Dentist Surgeon graduated from Federal University of Alagoas, UFAL, Brazil. ** Oral and Maxillo-Facial Surgeon Resident of University of Pernanbuco, UPE, and Dentist Surgeon graduated from Federal University of Alagoas, UFAL, Brazil.

*** Assistant Professor I of the Human Anatomy course at the Institute of Biologic and Health Sciences, Federal University of Alagoas, UFAL, with a Master's Degree in Morphology, Sao Paulo Federal University, UNIFESP, Brazil.

**** Surgeon Dentist from Federal University of Alagoas, UFAL, Brazil.

${ }^{* * * * *}$ Assistant Professor I of the Human Anatomy course at the Institute of Biologic and Health Sciences, Federal University of Alagoas, UFAL, with a Master's degree in Clinical Dentistry, Piracicaba, State University of Campinas, UNICAMP, Brazil. 
that it is used as a reference for an infraorbital nerve block and also used for plastic surgery and procedures of the facial maxillary area. It is of vital importance also in the practice of acupuncture, for in it the point Sibai (E2) is located (Chonghuo, 1993; Chen, 1997; Esper et al., 1997; 1998) and also in modern day surgical procedures like anesthesia, requiring a detailed and precise study of topographic anatomy and biometry of the area, which contributes also to the risk reduction and decrease in complications that could occur as a result of these procedures. Many studies of the biometric evaluation of the infraorbital foramen have been done. Nevertheless, the results have shown a large variation due to the fact that different anatomical markings were used as references in relation to this foramen, as well as variations in size, shape and symmetry of the foramen were seen.

The objective of this study was to do a morphological and biometric study of the infraorbital foramen, as well as to verify its symmetry with the counter-lateral. Simultaneously this study also was determined to orientate the Point E2 (Sibai), relating it with the reference points in the skull bones.

\section{MATERIAL AND METHOD}

The measurements were directly obtained from a total of 60 dry skulls which were obtained from the Higher Learning Institutions in the state of Alagoas, with the help of a manual pachymeter with graduations in millimeters, (MYTUTOYO, JAPAN). This study was properly approved by the Research Ethics Committee involving humans of the Federal University of Alagoas. A criteria of exclusion was adopted in any skull that showed signs of damage to the pear-shaped opening, the medial, lateral, upper or lower margins of the orbit, as well as skulls where the Infraorbital foramen (FIO) was found damaged unilaterally or bilaterally, in all cases; in all the samples the presence of a complete maxillary bone was considered to be mandatory, to be absolutely certain of the study of the foramens, due to the fact that both the foramen and the maxillary bone had to come from the same original skull. The skulls of children were not analyzed, only of adults, with no restrictions as to the adult age. The variations of sex and ethnic group were not considered.

The variations of situations, localization in relation to the center of the foramen and its medial, lateral, upper and lower margins, size, disposition, and the quantity of the openings of the infraorbital foramen were observed, as well as an analysis of its position in relation to the sagittal plane that passes through the center of the foramen/supraorbital incision. At this point an imaginary sagittal plane was used to classify the foramen in relation to the medial, lateral or in the same direction as this sagittal plane.

As far as the shape of the foramen, it was classified into four types:

Type I: Oval horizontal shape

Type II: Oval vertical shape

Type III: Round shape

Type IV: Semilunar (Half moon) shape

Sagittal Measurement: An imaginary sagittal plane that passes through the center of the infraorbital foramen, parallel to the medial sagittal plane. With the help of the manual pachymeter the values between the infraorbital margin and the upper margin of the infraorbital foramen were obtained as well as the distance between the upper margin of the orbit and the upper margin if he FIO.

Transversal Measurement: A transversal plane that passes through the center of the infraorbital foramen, forming an angle of 90 degrees with the adopted imaginary sagittal plane, that also passes through the center of the foramen, parallel



Fig. 1. Sagital and Transversal measurements. A. Distance between the IF and LBO. B. Distance between the IF and UBO. C. Distance between the IF and MBO. D. Distance between the IF and LBO. E. Distance between the IF and PO. 
to the medial sagittal plane. With help of the manual pachymeter we obtained measurements of the distance between the medial margin of the FIO and the lateral blade of the pear-shaped opening. Also, with the help of the manual pachymeter, values were obtained of the distances between the medial margin of the FIO and the medial margin of the orbit and of the lateral margin of the FIO and the lateral margin of the orbit (Fig. 1).

The position of the FIO in relation to the zigomaticmaxillary suture were considered, when this passes through the infraorbital margin. At this point an imaginary sagittal plane was used to classify the foramen into a position, medial, lateral or same direction of the sagittal plane. Also the location of the foramen in relation to the radicular apexes of the upper teeth and/or the alveolar process of the corresponding teeth was evaluated.

The measurements that were obtained were analyzed using the analytical methods of Variance, to obtain the measurement and the deviation pattern, T- Test to analyze the meaning of the Variance, for parametric data and the Qui-Quadrant for non parametric data, all of which showed a significance of 5\%, using the software SPSS 10.0 for Windows.

\section{RESULTS}

The infraorbital foramen (FIO) was present in all of the foramens analyzed. On the right side, the FIO was found located $6.49( \pm 1.68) \mathrm{mm}$ from the lower margin of the orbit (MIO), and 39.6( \pm 3$) \mathrm{mm}$ from the upper margin (MSO), from the medial margin (MMO) it was $17.7( \pm 2.97) \mathrm{mm}$ and to the lateral margin of the orbit (MLO) it was 20.46( \pm 2.9$)$ $\mathrm{mm}$. The distance found between the FIO and the pear-

\section{Sagittal Measures Correlations}

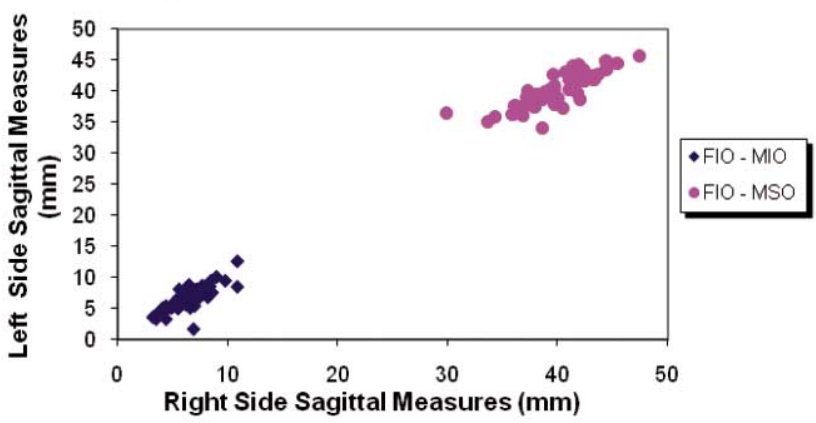

Fig. 2. Correlations of sagittal measures of infraorbital foramen. shaped opening (AP) was 13.67( \pm 2.17$)$. On the left side, the biometric analysis showed the following results: the distance of the FIO to the MIO was $6.52( \pm 1.82) \mathrm{mm}$; the distance to the MSO was $39.9( \pm 2.62) \mathrm{mm}$; the distance to the lateral margin and the medial foramen was $17.93( \pm 1.82) \mathrm{mm}$ and $21.12( \pm 3) \mathrm{mm}$, respectively and to the pear-shaped opening were $14.26( \pm 1.83) \mathrm{mm}$. The largest horizontal diameter of the FIO found was $4.2( \pm 0.95) \mathrm{mm}$ on the right side and $4.33( \pm 0,92) \mathrm{mm}$ on the left side, while the largest vertical diameter on the right side was $2.96( \pm 0.85) \mathrm{mm}$ and on the left side $3.17( \pm 0.89) \mathrm{mm}$.

The biometric data above analyzed and correlated were significant $(\mathrm{p}<0.05)$ and did not differ statistically in relation to its counter-lateral (Figs. 2 and 3).

The oval shaped foramen was found to be predominate, in $39(65 \%)$ of the skulls, on the right side as well as on the left, of which $30(76.92 \%)$ were on the right side presenting as the largest diameter being horizontal (Type I) and $9(23.08 \%)$ the vertical diameter was the largest (Type II). On the left side, of the 39 foramens found with an oval shape, $28(71.80 \%)$ had the largest diameter being the horizontal (Type I) and 11 (28.20\%) having the vertical as the largest diameter (Type II).

In 7 skulls, the FIO was found to be round (Type III) bilaterally (43.8\% and 50\%, for the right and the left sides, respectively.

The above analyzed data were statistically significant $(\mathrm{p}<0.05)$.

The pattern of variation in relation to the presence of the supranumerical foramens is shown in Table I.

In relation to the sagittal plane that passes through

\section{Transversal Measures Correlations}

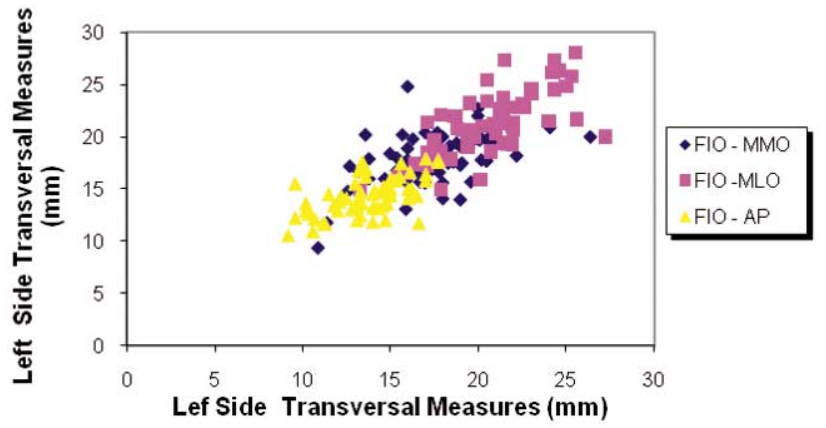

Fig. 3. Correlations of transversal measures of infraorbital foramen. 
Table I. Acessory foraminas.

\begin{tabular}{lcc}
\hline \multicolumn{1}{c}{ Foraminas } & Right Side & Left Side \\
\hline Present & $11(18.3 \%)^{*^{\mathrm{n}}}$ & $15(25 \%)^{*^{\mathrm{n}}}$ \\
Ausent & $49(81.7 \%)^{*^{\mathrm{n}}}$ & $45(75 \%) *^{\mathrm{n}}$ \\
\hline${ }^{*} \mathrm{p}<0.05$ n not estatistically differ. &
\end{tabular}

the center of the foramen/supraorbital incisure (FSO), the FIO was found more frequently laterally to it, in 38 skulls $(63.3 \%)$ on the right side and in 45 skulls $(75 \%)$ on the left side (Table II).

Table II. Sagittal Plan at Supraorbital Foramen/Incisure (SOF).

\begin{tabular}{lcc}
\hline Plano Sagittal: SOF & Right Side & Left Side \\
\hline Same Position & $12(20 \%)^{\mathrm{n}}$ & $8(13.3 \%)^{\mathrm{n}}$ \\
Medial & $10(16.7 \%)^{* \mathrm{n}}$ & $7(11.7 \%)^{* \mathrm{n}^{\mathrm{n}}}$ \\
Lateral & $38(63.3 \%)^{*}$ & $45(75 \%)^{*}$ \\
\hline${ }^{*}<0.05$ n not estatistically differ. &
\end{tabular}

In 31 skulls, (83.8\% of the cases on the right side and $68.9 \%$ for the left side), it was seen that when on the side that the FIO is located laterally to the sagittal plane that passes through the center of the foramen/supraorbital incisure, its counter-lateral did the same. The above analyzed data were significant $(\mathrm{p}<0.05)$.

In 39 cases, the FIO was found medial to the zigomatic-maxillary suture bilaterally $(95.1 \%$ on the right side and in $92.9 \%$ on the left side) (Table III).

Tabela III. Zigomático-Maxilar Suture.

\begin{tabular}{lcc}
\hline Zigomático-Maxilar Suture & Right Side & Left Side \\
\hline Same Position & $10(16.75 \%)^{*}$ & $6(10 \%)^{*}$ \\
Medial & $41(68.3 \%)^{*}$ n & $42(70 \%)^{*}$ \\
Lateral & $9(15 \%)^{* \mathrm{n}}$ & $12(20 \%)^{*}$ \\
\hline * p $<0.05$ n not estatistically differ. & &
\end{tabular}

The FIO was most frequently located between the first and the second upper premolars in 22 skulls (36.7\%) on the right side and in 17 skulls $(28.3 \%)$ on the left.

In 13 skulls, the FIO was found between the first and second premolars on the right side as well as on the left $(59.1 \%$ and $76.5 \%$ respectively (Table IV).

Table IV. Dental relationship.

\begin{tabular}{lcc}
\multicolumn{1}{c}{ Dental Relationship } & Right Side & Left Side \\
\hline Between the canine and $1^{\circ}$ pre-molar & 0 & $1(1.7 \%)$ \\
$1^{\text {st }}$ pre-molar & $4(6.7 \%)^{*}$ & $9(15 \%)^{*}$ \\
Between the $1^{\text {st }}$ and 2nd pre-molars & $22(36.7 \%)^{* \mathrm{n}}$ & $17(28.3 \%)^{* \mathrm{n}}$ \\
$2^{\text {nd }} \mathrm{p}_{\text {re-molar }}$ & $13(21.6 \%)^{* \mathrm{n}}$ & $11(18.3 \%)^{*^{\mathrm{n}}}$ \\
Between the $2^{\text {nd }}$ pre-molar and o $1^{\mathrm{t}}$ molar & $3(5 \%)^{\mathrm{n}}$ & $2(3.3 \%)^{\mathrm{n}}$ \\
\hline
\end{tabular}

$* \mathrm{p}<0.05 \mathrm{n}$ not estatistically differ.
The above analyzed data were statistically significant $(\mathrm{p}<0.05)$.

No cases were observed in which the FIO was located between the second premolar and the first molar bilaterally.

\section{DISCUSSION}

The Point E2 (Sibai - "Always Glowing") is located under the eye, being indicated principally for the treatment of eye alterations, for example blurred vision, hyperemia (edema) of the lids and itching with a light opacity of the cornea, according to Ming (1996), besides giving more brilliance to the eyes. This is the reason that it has the name Sibai (Ding, 1996).

According to Sussmann (1972) the E2 is located three decimals cun (inches) or three fens distal from to the E1 (Chegqui), in an infraorbital bone groove, this fact being in accordance also with the work that was reported by Xinnong (1999).

Ding, also affirmed that a needle could be inserted obliquely as well as perpendicularly at approximately 0.3 to 0.5 cun (inches) of profundity (depth). According to Xinnong the needle should be inserted perpendicularly, 0.2 to 0.3 inches, this work does not recommend that the needle be inserted profoundly (deeply).

For Esper et al. (1997), the largest clinical effect was found with the oblique insertion, at the Point E2 (Sabai), at an angle of 28.5 degrees in the frontal plane, 123.7 degrees in the transversal plane and 60.4 degrees in the coronal plane, rather than a perpendicular insertion. For Lee et al. (2006) the angle of the needle should be above 44 degrees to avoid injuring the infraorbital nerve.

The present study revealed that the infraorbital foramen (FIO) presented itself most often as a single foramen, of oval form, on both sides. It was located most frequently lateral to the sagittal plane that passes through the center of the supraorbital foramen/incisure, medial to the zigomaticmaxillary suture (when it is found on the lower margin of the orbit) and in the region of the superior premolars, on the right side as well as on the left side.

One other important variable that was considered in this study, in relation to the practice of anesthesia in the referred to foramen, was the presence of 
supranumerical foramens, present in 11(18.3\%) of the skulls on the right side and in $15(25 \%)$ of the skulls on the left side.

In relation to the presence of the supranumerical foramens a double foramen was found in 4 skulls, bilaterally in only one case. The presence of 2 triple foramens was observed, all on the right side.

Hindy \& Abdel-Raouf (1993) related that the FIO was fond in an opposite position to the second maxillary premolar in $50 \%$ of the cases, being a single foramen in $90 \%$ of the cases and a double foramen in $10 \%$. The oval shape of the foramen was found in $65 \%$ of the samples, differing from our study only in relation to the location as to the maxillary teeth, but being in accordance in relation to the shape and number.

According to Chung et al. (1995), the FIO was located in the same plane that passes through the supraorbital foramen/incisure ( $36.4 \%$ of the cases) or laterally to (on the side of) this plane (63.3\% of the cases). The supraorbital foramen/incisure, the FIO and the mental foramen were found in the same plane in $38.1 \%$ of the cases. More commonly, the infraorbital foramen was found laterally to the sagittal plane that passes through the supraorbital foramen/incisure, not differing from the results found in this study.

Canan et al. (1999), morphometrically analyzed, 119 skulls and 229 maxillas (in a total of 467 infraorbital foramens), in relation to the accessory foramens, and a single accessory foramen was found in $11.5 \%$ of the specimens and a double accessory foramen was present in $1.8 \%$ of the specimens, not differing statistically from the findings in the present analysis.

For Kazkayasi et al. (2001), the oval shape of the FIO was found in $34.3 \%$, a round shape in $38.6 \%$ and a semilunar (half moon) shape in $27.1 \%$ of the total number of skulls analyzed ( 35 dry adult skulls- 70 sides), differing from the results found in this study, where the oval shape of the foramen was predominate. The foramen was single in $94.3 \%$ and double in $5.7 \%$ of the cases, not differing statistically from our analysis.

Monroy et al. (2003), in a study of 165 dry skulls, observed that the form of FIO most commonly found was oval, present in $60 \%$ of the cases. The second premolar was found to have a relationship with this FIO in $94 \%$ of the specimens. On the other hand, the accessory infraorbital foramen was evidenced in $24.84 \%$ of the specimens, having its most common location supra-medial, in $79.26 \%$ of the cases.
Elias et al. (2004), related that in approximately $99 \%$ of the cases that they analyzed, they saw that the foramens observed the following relationship: if one was located medially (in relation to the sagittal plane that passes through the center of the zigomatic-maxillary suture as it crosses the infra-orbital margin) the other also had the same location, or if one was located laterally (on the side of) the plane, the other appeared in the same location. The only exceptions to this were found in 4 foramens, in 2 skulls, of the 324 skulls analyzed, in which one was medial to the plane and the other was found in the same position as this. The following results of the foramens were found in relation to the adopted plane that passes through the center of the supraorbital foramen: a) medial $(60.25 \%)$; b) lateral $(8.11 \%)$; c) on the plane (30.64\%).

As to the location of the FIO in relation to the upper maxillary teeth, our studies revealed that the foramen was most commonly found between the first and the second premolars, on the right side (22 skulls - 36.7\%) as well as on the left side (17 skulls - 28.3\%); it was found above the second premolar on the right side in $13(21.6 \%)$ of the skulls and in $11(18.3 \%)$ of the skulls on the left side. The foramen was found at the level of the first premolar in $4(6.7 \%)$ of the skulls on the right side and in $9(15 \%)$ on the left side.

Hindy \& Abdel-Raouf related that the FIO was found opposite to the second maxillary premolar in $50 \%$ of the cases, opposite to the first premolar in $15 \%$ and between the first and second premolars in $15 \%$ of the cases. As for Monroy et al., the second premolar was found to have a relation to the FIO in $94 \%$ of the specimens, this being in accordance with our findings.

A biometric analysis of this study demonstrated that the FIO (Point E2-Sibai), on the right side, was found $6.49( \pm 1.68) \mathrm{mm}$ from the lower margin of the orbit (MIO),39.65( \pm 3$) \mathrm{mm}$ from the upper margin (MSO), $17.7( \pm 2.97) \mathrm{mm}$ from the medial margin (MMO), and $20.46( \pm 2.9) \mathrm{mm}$ from the lateral margin of the orbit (MLO). The distance found between the foramen and the pear-shaped opening (AP) was $13.67( \pm 2.17) \mathrm{mm}$. On the left side, the biometric analysis obtained the following results: the distance of the FIO to the MIO was $6.52( \pm 1.82) \mathrm{mm}$; to the MSO was $39.9( \pm 2.62) \mathrm{mm}$; to the lateral and the medial margins $17.93( \pm 2.58) \mathrm{mm}$ and $21.12( \pm 3) \mathrm{mm}$, respectively, and to the AP was $14.26( \pm 1.83) \mathrm{mm}$.

The largest horizontal diameter of the FIO was found to be $4.2( \pm 0.95) \mathrm{mm}$ on the right side, and $4.33( \pm 0.92) \mathrm{mm}$ on the left side, while the largest vertical diameter found was $2.96( \pm 0.85) \mathrm{mm}$ on the right side and $3.17( \pm 0.89) \mathrm{mm}$ on the left side. 
According to Hindy \& Abdel-Raouf the distance from the center of the FIO to the infraorbital margin was $6.1( \pm 2.4) \mathrm{mm}$ and to the lateral nasal margin $14.7( \pm 2.7)$ $\mathrm{mm}$, statistically similar to our analysis.

Chung et al. (1995) related that the average distance of the medial sagittal plane to the center of the FIO was $27.2 \mathrm{~mm}$ and the infraorbital margin to the center of the FIO was $8.6 \mathrm{~mm}$; the average length of the line that goes from the center of the supraorbital foramen/incisure to the center of the FIO was $45.6 \mathrm{~mm}$. The average horizontal width of the foramen was found t be $4.8 \mathrm{~mm}$, not differing statistically from our findings.

According to Esper et al., the Point E2 (Sibai) located in the human adult skull was $6.8 \mathrm{~mm}$ under the lower orbital margin, $30.1 \mathrm{~mm}$ above the dental alveolar of the second upper premolar and $27.1 \mathrm{~mm}$ to the side of the anterior medial line, not differing statistically from our analysis, other than the location of the upper maxillary teeth.

For Kazkayasi et al., the average distances of the FIO to the infraorbital margin, to the lateral process (groove) of the upper canine tooth in a vertical direction and to the lateral nasal margin in a horizontal direction were $7.19( \pm 1.39) \mathrm{mm}, 33.94( \pm 3.15) \mathrm{mm}$, and $17.23( \pm 2.64)$ $\mathrm{mm}$, respectively, in accordance with our analysis.

For Karakas et al. (2003) the distance of the FIO to the infraorbital margin was $6.7( \pm 1.9) \mathrm{mm}$, presenting similar statistically with our analysis.

Monroy et al. affirmed that in relation to the distance between the center of the FIO to the lower margin of the orbit, along the medial plane and the zigomatic-maxillary suture, the data obtained were $6.9( \pm 3.18) \mathrm{mm}$ and 15.5 $( \pm 4.6) \mathrm{mm}$, respectively. For Cutright et al. (2003), confirmed that the FIO was located at an average distance of $27 \mathrm{~mm}$ from the medial nasal margin. The same foramen was found situated $6.4 \mathrm{~mm}$ under the infraorbital margin and medially $3 \mathrm{~mm}$ from the zigomatic-maxillary suture.

Elias et al. related that the average distance of the upper margin of the FIO to the lower margin of the orbit (sagittal medial) was found to be $6.71( \pm 1.70) \mathrm{mm}$ on the right side and $6.83( \pm 1.83) \mathrm{mm}$ on the left side; the distances of the medial margin of the FIO to the pear-shaped opening (transverse medial) was found to be $13.28( \pm 2.17) \mathrm{mm}$ and $13.31( \pm 2.19) \mathrm{mm}$ on the right and the left sides, respectively, not differing statistically, and presenting very similar to our analyses.

\section{CONCLUSION}

With our analyses it was confirmed that the FIO is located:

- At $6.49( \pm 1.68) \mathrm{mm}$ on the right and at $6.52( \pm 1.82) \mathrm{mm}$ on the left of the lower margin of the orbit.

- At $39.65( \pm 3) \mathrm{mm}$ and at $39.9( \pm 2.62) \mathrm{mm}$ from the upper margin of the orbit, on the right and the left sides, respectively.

- At 17.7( \pm 2.97$) \mathrm{mm}$ from the medial margin of the orbit and at $20.46( \pm 2.9) \mathrm{mm}$ from the lateral, on the right side and on the left side 17.93( \pm 2.58$) \mathrm{mm}$ and $21.12( \pm 3) \mathrm{mm}$ distant to the lateral and the medial (middle) margin of the orbit.

- At $13.67( \pm 2.17) \mathrm{mm}$ and at $14.26( \pm 1.83) \mathrm{mm}$ from the pearshaped opening, on the right and the left sides, respectively.

The oval shape was found to be predominant, on the right side as well as on the left. With accessory foramens present in 11 samples (18.3\%) on the right side and in 15 samples $(25 \%)$ on the left side.

The FIO was found most frequently lateral to the sagittal plane that passes through the center of the supraorbital foramen/incisure, medial to the zigomatic-maxillary suture and in the region between the first and second premolars, on the right side as well as on the left side.

AKNOWLEDGEMENTS. The authors would like to thank the Institute of Biological Sciences (ICBS) and the Departments of Morphology of the Institutions of Higher Education that furnished data for this study.

OLIVEIRA JUNIOR, E. M. de; MOREIRA, R. T.; NETO, B. L.; SILVA, C. M. F. da \& LIMA, F. J. C. A. Estudio morfológico y biométrico del foramen infraorbital (punto E2-Sibai) en cráneos de adultos. Int. J. Morphol., 30(3):986-992, 2012.

RESUMEN: El objetivo de este trabajo fue estudiar la morfología y biometría del foramen infraorbitario (FIO), las variaciones en su forma, tamaño y número y además, determinó su ubicación. Se utilizaron 60 cráneos aplicándose las prueba de Chicuadrado y t student con una significancia del 5\%. En el lado derecho, la distancia del FIO al margen inferior de la órbita fue de $6,49( \pm 1,68) \mathrm{mm}, 39,65 \mathrm{~mm}( \pm 3)$ al margen superior $\mathrm{mm}, 17,7$ $\mathrm{mm}( \pm 2,97)$ al margen medial y $20,46( \pm 2,9)$ y al margen lateral de la órbita, respectivamente. La distancia de apertura fue 13,67 ( \pm $2,17) \mathrm{mm}$. En el lado izquierdo, la distancia del FIO al margen inferior de la órbita fue $6,52( \pm 1,82) \mathrm{mm}$; al margen superior fue 
$39,9( \pm 2,62) \mathrm{mm}$ y a los márgenes lateral y medial fue 17,93 $2,58) \mathrm{mm}$ y $21,12( \pm 3) \mathrm{mm}$, respectivamente. La distancia a la abertura piriforme fue $14,26( \pm 1,83) \mathrm{mm}$. Su forma era predominantemente ovalada, en 39 (65\%) de los cráneos. Forámenes accesorios estaban presentes en 11 muestras en el lado derecho y en 15 muestras en el lado izquierdo. El FIO estaba localizado más frecuentemente lateral al plano sagital que pasa por el centro del foramen supraorbital. De estos casos, en 38 cráneos $(63,3 \%)$ en el lado derecho y en 45 cráneos (75\%) en el lado izquierdo. Los FIO estaban en el punto medio de la sutura cigomática-maxilar en 41 cráneos $(68,3 \%)$ en el lado derecho y en 42 cráneos (70\%) en el lado izquierdo. Los FIO estaban más frecuentemente localizados en relación al primer y segundo premolares, en 22 cráneos (36,7\%) en el lado derecho y en 17 cráneos $(28,3 \%)$ en el lado izquierdo

PALABRAS CLAVE: Foramen infraorbital (E2-Sibai Point); Acupuntura; Biometría.

\section{REFERENCES}

Berge, J. K.; Bergman, R. A. Variations in size and in symmetry of foramina of the human skull. Clin. Anat., 6:406-13, 2001.

Chen, E. Anatomia topográfica dos pontos de acupuntura. São Paulo, Roca, 1997.

Chonghuo, T. Tratado de Medicina Chinesa. São Paulo, Roca, 1993.

Chung, M. S.; Kim, H. J.; Kang, H. S. \& Chung, I. H. Locational relationship of the supraorbital notch or foramen and infraorbital and mental foramina in Koreans. Acta Anat., 154:162-6, 1995.

Cutright, B.; Quillopa, N. \& Schubert, W. An anthropometric analysis of the key foramina for maxillofacial surgery. J. Oral Maxillofac. Surg., 61(3):354-7, 2003.

Ding, L. Acupuntura, Teoria do Meridiano e Pontos de Acupuntura. 1a ed. São Paulo, Rocca, 1996.

Elias, M. G.; Silva, R. B.; Pimentel, M. L.; Cardoso, V. T. S.; Rivello, T. \& Babinski, M. Morphometric analysis of the infraorbital foramen and acessories foraminas in Brazilian skulls. Int. J. Morphol., 22(4):273-8, 2004.

Esper, R. S.; Yamamura, Y; Cricenti, S. V. \& Novo, N. F. Efeitos da inserçäo perpendicular e oblíqua de agulhas no ponto de acupuntura E-2 (Sibai), no forame infra-orbital. Rev. Paul. Acupunt., 3(2):85-8, 1997.

Esper, R. S.; Yara. J.; Yamamura, Y. \& Cricenti, S. V. Relações anatômicas do ponto de acupuntura E-2 (Sibai) localizado no forame infra-orbital. Rev. Paul. Acupunt., 4(1):19-22, 1998.

Gardner, E.; Gray, D. J. \& O'hailly, R. Anatomia: estudo regional do corpo humano. 4. ed. Rio de Janeiro, Guanabara Koogan, 1988.
Hindy, A. M. \& Abdel-Raouf, F. A study of infraorbital foramen, canal and nerve in adult Egyptians. Egypt Dent. J., 39(4):57380, 1993.

Karakas, P.; Bozkir, M.G. \& Oguz, Ö. Morphometric measurements from various reference points in the orbit of male Caucasians. Surg. Radiol. Anat., 24(6):358-62, 2002.

Kazkayasi, M.; Ergin, A.; Ersoy, M.; Bengi, O.; Tekdemir, I. \& Elhan, A. Certain anatomical relations and the precise morphometry of the infraorbital foramen, canal and groove: an anatomical and cephalometric study. Laryngoscope, 111(4 Pt 1):609-14, 2001.

Lee, U. Y.; Nam, S. H.; Han, S. H.; Choi, K. N. \& Kim, T. J. Morphological characteristics of the infraorbital foramen and infraorbital canal using three-dimensional models. Surg. Radiol. Anat., 24:1-6, 2006.

Ming, S. X. Os Fundamentos da Medicina Chinesa Um Texto Abrangente para Acupunturistas e Fitoterapeutas. São Paulo, Rocca, 1996.

Monroy, C.; Liliana, P.; Morales, M.; Andrés, C.; Jacome, N.; Anibal, J. \& Cassiano, C. G. Características y variaciones anatómicas del surco, canal y foramen infraorbitario en un grupo de población colombiana. Univ. odontol., 23(52):60-8, 2003.

Ranali, J.; Andrade, E. D. \& Matos Filho, T. R. Anestesia dos nervos alveolar inferior, lingual e bucal: análise das técnicas convencionais e a de Gow-Gates. Rev. Paulista de Odontologia. 5:12-6, 1988

Sischer \& Dubrul. Anatomia oral. 8. ed. São Paulo, Artes Médicas, 1991.

Sussmann, D. J. Que é a Acupuntura? 2a ed. Rio de Janeiro, Record, 1972.

Teixeira, L. M. S.; Reher, P.\& Reher, V. G. S. Anatomia aplicada à odontologia. Rio de Janeiro, Guanabara Koogan, 2001.

Testut, L. \& Latarjet, A. Tratado de anatomía humana. Barcelona, Salvat Editores, 1954.

Xinnong, C. Acupuntura e Moxibustão Chinesa. São Paulo, Rocca, 1999.

\section{Correspondence to:}

Edson Matins de Oliveira Junior

Oral and Maxillo-Facial Surgery

São Paulo University

Universidadede São Paulo - USP

São Paulo

BRAZIL

E-mail: jr.odonto@gmail.com

Received: 12-12-2011

Accepted: 16-03-2012 